\title{
Ellenoldali csípőtáji törésekkel összefüggő halálozás és kockázati tényezőinek vizsgálata
}

\author{
Juhász Krisztina dr. ${ }^{1}$ - Boncz Imre dr. ${ }^{2,3}$ - Kanizsai Péter dr. ${ }^{4}$ \\ Mester Sándor dr. ${ }^{5}$. Sebestyén Andor dr. ${ }^{2,3}$ \\ ${ }^{1}$ Baranya Megyei Kormányhivatal, Pécsi Járási Hivatal, Népegészségügyi Osztály, Pécs \\ ${ }_{2}^{2}$ Pécsi Tudományegyetem, Egészségtudományi Kar, Egészségbiztosítási Intézet, Pécs \\ ${ }^{3}$ Pécsi Tudományegyetem, Klinikai Központ, Pécs \\ ${ }^{4}$ Semmelweis Egyetem, Klinikai Központ, Sürgősségi Betegellátó Osztály, Budapest \\ ${ }^{5}$ Pécsi Tudományegyetem, Klinikai Központ, \\ Balesetsebészeti és Kézsebészeti Klinika, Pécs
}

\begin{abstract}
Bevezetés: Az ellenoldali csípőtáji töréseket követő halálozás magas, kockázati tényezőikről kevés adat ismert. Célkitüzés: Ellenoldali csípőtáji törések 30 napon, és 365 napon belüli halálozásának és kockázati tényezőinek vizsgálata. Módszer: Retrospektív tanulmányunk alapját a 2000-ben combnyaktörés miatt operált időskorú betegek képezték, akik 2008. december 31-ig ellenoldali csípőtáji törést szenvedtek. A vizsgált kockázati tényezők az életkor, nem, kísérő betegség, törés lokalizációja, műtét típusa, lokális szövődmények, intézményi felvétel napja, amelyet logisztikus, Cox-regressziós és Kaplan-Meyer-analízissel értékeltünk.

Eredmények: A kritériumoknak 312 beteg felelt meg, 8,3\%-os 30, illetve 38,4\%-os 365 napon belüli halálozással. A 30 napon belüli halálozás szignifikáns kockázati tényezői a pertrochantaer töréstípus $\left(\mathrm{EH}_{\text {pertrochantaer } / \text { combnyak }}=4,722\right.$, $\left.\mathrm{VH}_{\text {pertrochantaer/combnvak }}=4,129\right)$ és a mútét hiánya $\left(\mathrm{EH}_{\text {nincs mútét/osteosynthesis }}=7,357, \mathrm{VH}_{\text {nincs mútét/osteosynthesis }}=6,317\right)$, a 365 napon belüli halálozásnál az idősebb kor $\left(\mathrm{EH}_{\text {korév }}=1,070, \mathrm{VH}_{\text {korév }}=1,050\right)$ és az osteosynthesis mútéti típus $\left(\mathrm{EH}_{\text {arthroplastica/osteosynthesis }}=0,450\right)$.

Következtetés: A kor, a töréstípus és a mútét típusa kockázati tényezőnek bizonyult. Az ellenoldali csípőtáji törések okozta halálozást csökkentő effektív preventív stratégia kialakításához további kockázati tényezők elemzése szükséges. Orv Hetil. 2017; 158(20): 783-790.
\end{abstract}

Kulcsszavak: ellenoldali csípőtáji törés, kockázati tényezők, halálozás, túlélés

\section{Analysis of mortality and its predictors in patients with contralateral hip fracture after femoral neck fracture}

Introduction: There is a high mortality with not well understood risk factors after the second hip fracture. Aim: Analysis of the 30- and 365-day mortality and its risk factors in patients with contralateral hip fracture. Method: Patients with contralateral hip fracture between 01 Jan 2000 and 31 Dec 2008 were identified among those who suffered their primary hip fracture in Hungary in 2000. Risk factors as age, sex, concomitant and chronic diseases, type of fracture and surgery, surgical complications, day of admission were analyzed by logistic and Cox regression as well as Kaplan-Meier analysis.

Results: There were 312 eligible patients identified with $8.3 \%$ mortality rate at 30 and with $38,4 \%$ at 365 days respectively. Significant risk factors for the 30 day mortality were intertrochanteric type of fracture (OR: 4.722; HR: 4.129) and non operative management (OR: 7.357; HR: 6.317) while for the 365 day mortality those were older age (OR:1.070; HR:1.050) and type of surgery (OR: 0.450).

Conclusion: Age, type of fracture and type of surgery proved to be risk factors. There is a need to identify further risk factors in order to develop an efficacious prevention strategy for the reduction of the mortality after the second hip fractures. 
Keywords: contralateral hip fracture, risk factors, mortality, survival

Juhász K, Boncz I, Kanizsai P, Mester S, Sebestyén A. [Analysis of mortality and its predictors in patients with contralateral hip fracture after femoral neck fracture]. Orv Hetil. 2017; 158(20): 783-790.

(Beérkezett: 2017. március 16.; elfogadva: 2017. április 12.)

\section{Rövidítések}

BNO = Betegségek Nemzetközi Osztályozása; CI = konfidenciaintervallum; $\mathrm{EH}=$ esélyhányados; $\mathrm{HR}$ = hazard ratio; $\mathrm{OEP}=$ Országos Egészségbiztosítási Pénztár; $\mathrm{OR}=$ odds ratio; $\mathrm{SD}=$ standard deviáció; $\mathrm{VH}$ = veszélyhányados

A csípőtáji törés az osteoporoticus csonttörések legsúlyosabb formája, amelyet gyakori előfordulása mellett magas mortalitás, életminőség- és funkciócsökkenés jellemez, miközben jelentős betegségterhet jelent az egészségügyi ellátórendszer és a családok számára egyaránt [1-4].

A csípótáji törések incidenciájáról számos [5-8] tanulmány számol be, amely 135-420/100 000 fó [9, 10] között alakul a korstandardizált vegyes populációnál. A szekunder vagy ellenoldali csípőtáji törések előfordulását is több tanulmány [11-15] vizsgálta, amelynek értéke 2,7-9\% között változik az első évnél. Hazai adatok alapján a combnyaktöréseket követő ellenoldali csípótáji törések előfordulásának kockázati tényezőiről korábbi tanulmányunkban [16] számoltunk be.

A csípőtáji töréseket követő halálozást számos nemzetközi [17-20], ugyanakkor kevés hazai [21] tanulmány vizsgálja, amelynek egyéves értékei 14-36\% között alakulnak $[22,23]$. Az ellenoldali csípőtáji töréseket követő mortalitásról hazai vonatkozásban nem, nemzetközi viszonylatban több $[11,15,24,25]$ tanulmány áll rendelkezésre, amelyek a kockázati tényezőit is értékelik.

Hiánypótló tanulmányunk célja a primer combnyaktöréseket követő ellenoldali csípőtáji törést szenvedett betegek halálozásának és a halálozás kockázati tényezőinek vizsgálata a szekunder törést követő első évben magyar populáción.

\section{Betegek és módszer}

A retrospektív kohorsztanulmányunk alapját az Országos Egészségbiztosítási Pénztár (OEP) adatai szerint azon - 2000-ben combnyaktörés (BNO: S7200) miatt primeren operált 60 éves és idősebb - betegek képezték, akik 2000. január 1. és 2008. december 31. között szenvedtek el ellenoldali csípőtáji törést.

A 2000. évből combnyaktörés diagnózissal (S7200 BNO-10) 5404 eset került leválogatásra az OEP adatbázisából, melyet az ellátó intézmények kontrolláltak és validáltak. 4943 esetre érkezett válasz a kórházaktól, amelyből kizárásra került 664 eset, mert 60 év alattiak voltak, 89 eset hiányzó vagy ellentmondásos kórházi adatok miatt, 259 eset régi törés, patológiás törés és egyéb törési diagnózis miatt, valamint 148 eset politrauma és szövődmény okozta további ellátás miatt. A 3783 validált, 2000-ben operált combnyaktörött beteg közül 312 betegnél alakult ki ellenoldali, 35 betegnél azonos oldali csípőtáji törés 2008. december 31-ig. Tanulmányunkban így a 312 ellenoldali csípőtáji törést értékeltük.

A halálozás értékelése során a halálozásig eltelt idő az ellenoldai csípőtáji törés intézményi felvételi dátumától kezdődően került megállapításra. A halálozási arányokat havonként és kumuláltan havonként is vizsgáltuk az ellenoldali csípőtáji törést követő első évben. A vizsgált prognosztikai tényezők tekintetében a 30 és 365 napos nyers halálozási értékek és arányok kerülnek bemutatásra. A halálozási arányok százalékban fejezik ki a vizsgált időperiódusban meghaltak számarányát. A betegre jellemző klinikai adatok/tulajdonságok az ellenoldai törés definitív ellátásakor észlelt állapotnak megfelelően kerültek rögzítésre.

A kockázati tényezôk közül az életkor (korév), a nem, a kísérő betegség jelenléte vagy hiánya, a törés lokalizációja (combnyaktörés, pertrochantaer törés, egyéb csípőtáji törés) és a mútét típusa (arthroplastica, osteosynthesis, operatív beavatkozás hiánya), a lokális operatív ellátást igénylő szövődmények jelenléte vagy hiánya, valamint az intézményi felvétel napja (hétköznap, hétvége) szerepét elemeztük az ellenoldali csípőtáji töréssel összefüggésben. A kísérő vagy társult betegség tényét a töréskor már meglevő vagy a törésellátás során diagnosztizált, töréssel közvetlenül nem összefüggő betegségek esetén rögzítettük. A lokális szövődménynél az ellenoldali csípőtáji törés primer definitív ellátását követő egy évben kivitelezett további mütéti beavatkozásokat (korai fémkivételek, szeptikus és aszeptikus feltárások, rediszlokáció miatti implantátumcserék, arthroplasticák, valamint a combfej vérellátását javító mütétek és osteotomiák) egységesen vettük figyelembe.

A kockázati tényezők és a halálozás (30 napon belül/365 napon belül) kapcsolatát többváltozós logisztikus és Cox-regessziós analízissel vizsgáltuk. A rizikótényezők prognózist (halálozási kockázat) meghatározó képességét esélyhányadosokkal $(\mathrm{EH})$ és veszélyhányadosokkal (VH) írtuk le. A 30 és 365 napos túlélés és az 
egyes kockázati tényezők kapcsolatát Kaplan-Meyeranalízissel és log-rank teszttel vizsgáltuk.

Szignifikanciaszintnek a $\mathrm{p} \leq 0,05$ értéket tekintettük. Az egyes értékeknél feltüntettük a hozzájuk tartozó 95\%-os konfidenciaintervallumokat (CI). Tekintettel az egyes tényezők gyakorlati jelentőségére, határérték-szignifikanciát $(0,05<\mathrm{p}<0,08)$ mutató értékeket is figyelembe vettünk. Az adatok értékelését SPSS 19.0 statisztikai programmal végeztük.

\section{Eredmények}

Tanulmányunk beválasztási kritériumainak 312 ellenoldali csípőtáji törést szenvedett beteg felelt meg. A betegek 84,3\%-a nő, 15,7\%-a férfi volt. Átlagéletkoruk az ellenoldali töréskor 80,97 év (SD 7,42) volt. A törés típusa szerint a betegek 29,5\%-a pertrochantaer, $65,1 \%$-a combnyak- és 5,4\%-a egyéb csípőtáji törést szenvedett. Kísérő betegség a betegek 96,8\%-ában, operatív lokális szövődmény 8\%-ban fordult elő. A betegek 16,7\%-ánál történt arthroplastica, 80,8\%-a osteosynthesisen esett át. A betegek 73,1\%-a hétköznap került felvételre (1. táblázat).

A halálozást havonként vizsgálva (1. ábra), legmagasabb értékeit az első és második hónapban (8,3\% és $9,0 \%)$ érte el, amelytől kezdve csökkenő tendenciát mutatott az ötödik hónapig, majd stagnált. A kumulált ha- lálozás alapján a mortalitás az első két hónapban 17,3\%, az első negyedévben 22,1\%, az első fél évben 29,5\%, az első évben $38,4 \%$ volt.

$\mathrm{Az}$ ellenoldali csípőtáji törést követő 30 napon belüli halálozás átlagosan $8,3 \%$, amely a nem alapján nóknél $7,2 \%$, férfiaknál $14,3 \%$, a törés típusa szerint a pertrochantaer töréseket követően 16,3\%, a combnyaktöréseknél 4,4\%; kisérö betegség esetén 8,6\%, a mütét típusa szerint az arthroplasticán átesett betegeknél 3,8\%, az osteosynthesisen átesett betegeknél 8,7\%, a korcsoportok alapján a 60-69 éves és 70-79 éves csoportoknál egyaránt $6,7-6,7 \%$, a 80-89 éveseknél 10,2\%, míg a felvétel napja szerint $8,3 \%$ a hétvégi és a hétköznapi felvételeket követően egyaránt (1. táblázat).

Az ellenoldali csípőtáji törést követő 365 napon belüli halálozás átlagosan $38,4 \%$, amely a nem alapján nőknél $36,5 \%$, férfiaknál 49,0\%, a törés típusa szerint a pertrochantaer töréseket követően $42,4 \%$, a combnyaktöréseknél 37,4\%, kiséró betegség esetén 39,4\%, hiányában 10\%, a mútét típusa szerint az arthroplasticán átesett betegeknél $21,2 \%$, az osteosynthesisen átesett betegeknél 41,3\%, a korcsoportok alapján a 60-69 éveseknél 23,3\%, míg a 90 év felettieknél 55\%, lokális szövödmény esetén 48\%, hiányában $37,6 \%$, a felvétel napja szerint a hétvégi felvételeket követően 35,7\%, a hétköznapok esetén 39,5\% (1. táblázat).

1. táblázat | Ellenoldali csípótáji törést szenvedett betegek demográfiai jellemzői, illetve a 30 napon belüli és 365 napon belüli halálozás értékei

\begin{tabular}{|c|c|c|c|c|c|c|c|}
\hline \multirow[t]{2}{*}{ Prognosztikai tényezők } & & \multicolumn{2}{|c|}{ Ellenoldali csípőtáji törések } & \multicolumn{2}{|c|}{30 napon belüli halálozás } & \multicolumn{2}{|c|}{365 napon belüli halálozás } \\
\hline & & Fö & Megoszlás (\%) & Fő & Arány (\%) & Fö & Arány (\%) \\
\hline \multirow[t]{4}{*}{ Korcsoport } & 60-69 év & 30 & 9,6 & 2 & 6,7 & 7 & 23,3 \\
\hline & 70-79 év & 105 & 33,7 & 7 & 6,7 & 30 & 28,6 \\
\hline & 80-89 év & 137 & 43,9 & 14 & 10,2 & 61 & 44,5 \\
\hline & 90 éves vagy idősebb & 40 & 12,8 & 3 & 7,5 & 22 & 55,0 \\
\hline \multirow[t]{2}{*}{$\mathrm{Nem}$} & Nő & 263 & 84,3 & 19 & 7,2 & 96 & 36,5 \\
\hline & Férfi & 49 & 15,7 & 7 & 14,3 & 24 & 49,0 \\
\hline \multirow[t]{2}{*}{ Kísérő betegség } & Van & 302 & 96,8 & 26 & 8,6 & 119 & 39,4 \\
\hline & Nincs & 10 & 3,2 & 0 & 0 & 1 & 10 \\
\hline \multirow[t]{3}{*}{ Törés lokalizációja } & Pertrochantaer törés & 92 & 29,5 & 15 & 16,3 & 39 & 42,4 \\
\hline & Combnyaktörés & 203 & 65,1 & 9 & 4,4 & 76 & 37,4 \\
\hline & Egyéb & 17 & 5,4 & 2 & 11,8 & 5 & 29,4 \\
\hline \multirow[t]{3}{*}{ Mútét típusa } & Arthroplastica & 52 & 16,7 & 2 & 3,8 & 11 & 21,2 \\
\hline & Osteosynthesis & 252 & 80,8 & 22 & 8,7 & 104 & 41,3 \\
\hline & Nincs & 8 & 2,5 & 2 & 25,0 & 5 & 62,5 \\
\hline \multirow[t]{2}{*}{ Lokális szövődmény } & Van & 25 & 8,0 & 1 & 4,0 & 12 & 48,0 \\
\hline & Nincs & 287 & 92,0 & 25 & 8,7 & 108 & 37,6 \\
\hline \multirow[t]{2}{*}{ Felvétel napja } & Hétköznap & 228 & 73,1 & 19 & 8,3 & 90 & 39,5 \\
\hline & Hétvége & 84 & 26,9 & 7 & 8,3 & 30 & 35,7 \\
\hline Összesen & & 312 & 100 & 26 & 8,3 & 120 & 38,4 \\
\hline
\end{tabular}




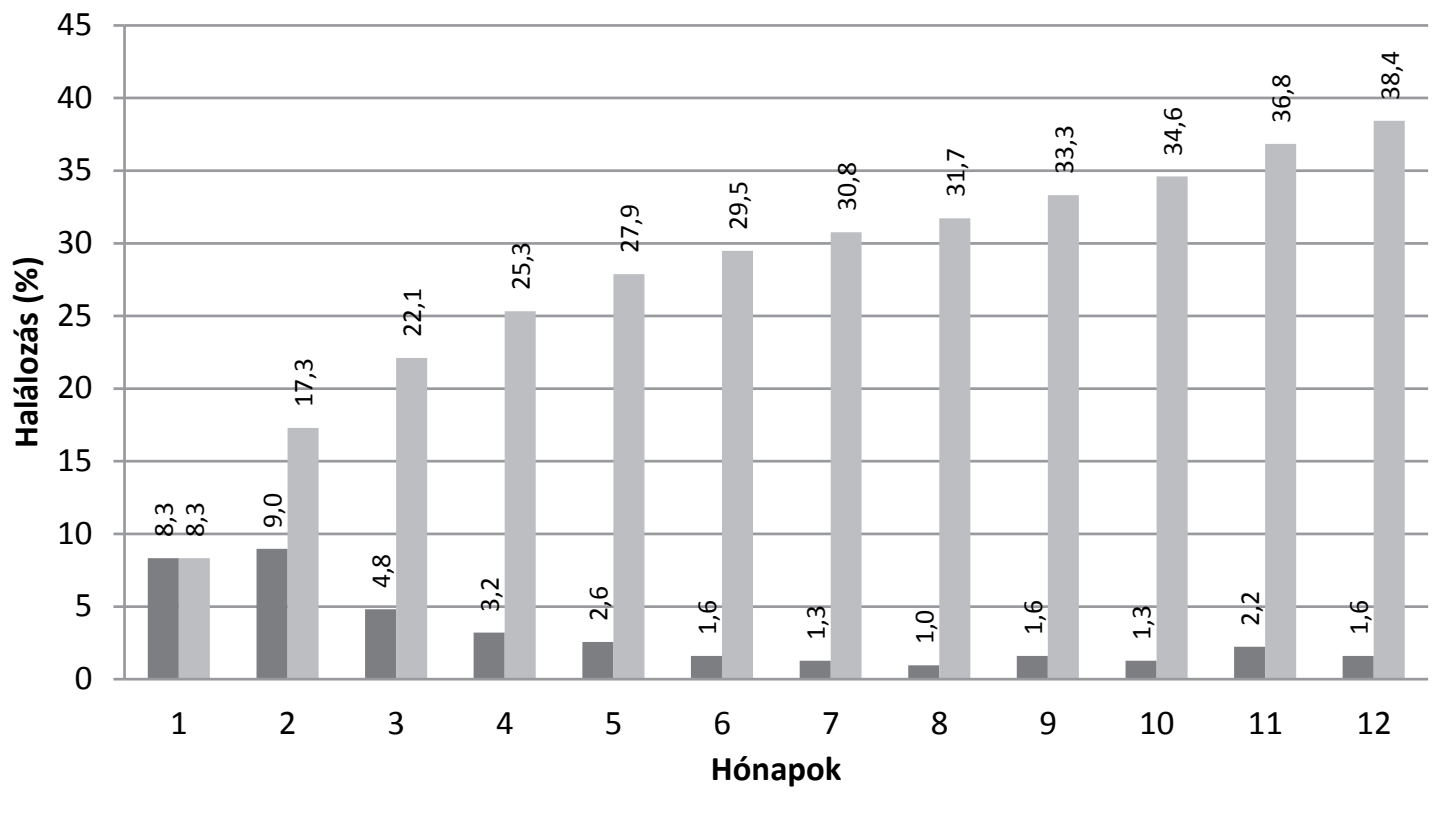

- Halálozás

Kumulatív halálozás

1. ábra | Ellenoldali csípőtáji töréseket követő halálozás (\%) és kumulált halálozás (\%) havonkénti megoszlása

A 30 napon belüli halálozásra a pertrochantaer töréstípus $\left(\mathrm{EH}_{\text {pertrochantaer/combnyak }}=4,722, \mathrm{p}=0,002 ; \mathrm{VH}_{\text {pert- }}\right.$ rochantaer/combnyak $=4,129, \mathrm{p}=0,003)$ és a mütét hiánya $\left(\mathrm{EH}_{\text {nincs mútét/osteosynthesis }}=7,357, \mathrm{p}=0,031 ; \mathrm{VH}_{\text {nincs mútét/ }}\right.$ osteosynthesis $=6,317, \mathrm{p}=0,025)$, míg a 365 napon belüli halálozásra az idősebb kor $\left(\mathrm{EH}_{\text {korév }}=1,070, \mathrm{p}=0,000\right.$; $\left.\mathrm{VH}_{\text {korév }}=1,050, \mathrm{p}=0,000\right)$ és az osteosynthesis mütéti típus $\left(\mathrm{EH}_{\text {arthroplastica/osteosynthesis }}=0,450, \mathrm{p}=0,043\right.$; $\left.\mathrm{VH}_{\text {arthroplastica/osteosynthesis }}=0,552, \mathrm{p}=0,072\right)$ jelent szignifikáns kockázatot (2. és 3. táblázat).

A nem szerepe a 30 napos $\left(\mathrm{EH}_{\text {nő/férfi }}=0,397, \mathrm{p}=\right.$ 0,$\left.067 ; \mathrm{VH}_{\text {nó/férfi }}=0,443, \mathrm{p}=0,074\right)$ és a 365 napon belüli halálozásnál $\left(\mathrm{VH}_{\text {nő/férfi }}=0,639, \mathrm{p}=0,053\right)$ statisztikailag nem szignifikáns, de határérték-szignifikanciája miatt gyakorlati jelentősége nem elhanyagolható (2. és 3. táblázat).

Nem jelent szignifikáns kockázatot a 30 napon belüli és a 365 napon belüli halálozásra az intézményi felvétel napja és a lokális szövődmény.

A kísérő betegség esetében - a vizsgált csoportok jelentősen eltérő elemszámai miatt - a statisztikai elemzések nem mutattak értékelhető adatokat, ezért a deskriptív leírás értékei alapján mind a 30 napon belüli, mind a 365 napon belüli halálozásnál a kísérő betegséget halálozási kockázatot növelő tényezőként vettük figyelembe.

A Kaplan-Meyer-túlélésanalízis alapján a 30 napos túlélésnél a törés lokalizációja $(\mathrm{p}=0,002)$, a 365 napos túlélésnél a nem $(\mathrm{p}=0,067)$ és a mútét típusa $(\mathrm{p}=0,019)$

2. táblázat | Ellenoldali csípőtáji törést követő, 30 és 365 napon belüli halálozás többváltozós logisztikus regressziós analízise

\begin{tabular}{|c|c|c|c|c|c|c|c|}
\hline \multirow[t]{2}{*}{ Prognosztikai tényezők } & & \multicolumn{3}{|c|}{30 napon belüli halálozás } & \multicolumn{3}{|c|}{365 napon belüli halálozás } \\
\hline & & $\mathrm{EH}$ & $95 \% \mathrm{CI}$ & $\mathrm{p}$ & $\mathrm{EH}$ & $95 \% \mathrm{CI}$ & $\mathrm{p}$ \\
\hline Kor & Korév & 1,041 & $0,980-1,106$ & 0,196 & 1,070 & $1,033-1,109$ & 0,000 \\
\hline Nem & Nő/férfi & 0,397 & $0,148-1,067$ & 0,067 & 0,577 & $0,301-1,105$ & 0,097 \\
\hline Kísérō betegség & Van/nincs & n. é. & & & n. é. & & \\
\hline \multirow[t]{2}{*}{ Törés lokalizációja } & Pertrochantaer/combnyak & 4,722 & $1,750-12,742$ & 0,002 & 1,053 & $0,609-1,821$ & 0,852 \\
\hline & Egyéb/combnyak & 2,428 & $0,433-13,620$ & 0,313 & 0,484 & $0,154-1,520$ & 0,214 \\
\hline \multirow[t]{2}{*}{ Mútét típusa } & Arthroplastica/osteosynthesis & 1,116 & $0,215-5,799$ & 0,896 & 0,450 & $0,208-0,975$ & 0,043 \\
\hline & Nincs/osteosynthesis & 7,357 & $1,197-45,229$ & 0,031 & 3,683 & $0,748-18,140$ & 0,109 \\
\hline Lokális szövődmény & Van/nincs & 1,387 & $0,045-3,322$ & 0,386 & 1,496 & $0,633-3,532$ & 0,359 \\
\hline Felvétel napja & Hétköznap/hétvége & 1,105 & $0,423-2,888$ & 0,839 & 1,194 & $0,685-2,081$ & 0,531 \\
\hline
\end{tabular}

A vizsgált prognosztikai tényezők közül a referenciaétékeket aláhúztuk.

$\mathrm{CI}=$ konfidenciaintervallum; $\mathrm{EH}$ = esélyhányados; n. é. = nem értelmezhető 
3. táblázat | Ellenoldali csípótáji törést követő, 30 és 365 napon belüli halálozás többváltozós Cox-regressziós analízise

\begin{tabular}{|c|c|c|c|c|c|c|c|}
\hline \multirow[t]{2}{*}{ Prognosztikai tényezők } & & \multicolumn{3}{|c|}{30 napon belüli halálozás } & \multicolumn{3}{|c|}{365 napon belüli halálozás } \\
\hline & & VH & $95 \% \mathrm{CI}$ & $\mathrm{p}$ & $\mathrm{VH}$ & $95 \% \mathrm{CI}$ & $\mathrm{p}$ \\
\hline Kor & Korév & 1,035 & $0,980-1,093$ & 0,213 & 1,050 & $1,024-1,077$ & 0,000 \\
\hline Nem & Nő/férfi & 0,443 & $0,181-1,081$ & 0,074 & 0,639 & $0,405-1,006$ & 0,053 \\
\hline Kísérő betegség & $\operatorname{Van} / \underline{\text { nincs }}$ & n. é. & & & n. é. & & \\
\hline \multirow[t]{2}{*}{ Törés lokalizációja } & Pertrochantaer/combnyak & 4,129 & $1,637-10,412$ & 0,003 & 1,176 & $0,787-1,757$ & 0,429 \\
\hline & Egyéb/combnyak & 2,089 & $0,415-10,507$ & 0,372 & 0,692 & $0,276-1,734$ & 0,432 \\
\hline \multirow[t]{2}{*}{ Mútét típusa } & Arthroplastica/osteosynthesis & 1,046 & $0,212-5,153$ & 0,956 & 0,552 & $0,289-1,054$ & 0,072 \\
\hline & Nincs/osteosynthesis & 6,317 & $1,256-31,769$ & 0,025 & 2,084 & $0,837-5,188$ & 1,115 \\
\hline Lokális szövődmény & $\operatorname{Van} / \underline{\text { nincs }}$ & 0,392 & $0,051-3,038$ & 0,37 & 1,255 & $0,688-2,290$ & 0,459 \\
\hline Felvétel napja & Hétköznap/hétvége & 1,128 & $0,464-2,746$ & 0,790 & 1,119 & $0,738-1,696$ & 0,598 \\
\hline
\end{tabular}

A vizsgált prognosztikai tényezők közül a referenciaétékeket aláhúztuk.

$\mathrm{CI}=$ konfidenciaintervallum; $\mathrm{n}$. é. = nem értelmezhető $\mathrm{VH}=$ veszélyhányados

esetében találtunk szignifikáns eltérést az egyes csoportok túlélési ideje között log-rank teszttel. A törés lokalizációját tekintve a legrosszabb túlélést a pertrochantaer, legjobbat a combnyaktörött betegeknél találtuk. Az egyéves túlélés nőknél jobb volt. Legrosszabb túlélés a definitív mútéti ellátásban nem részesült betegeknél igazolódott (2. ábra)

\section{Megbeszélés}

Tanulmányunk a 60 éves és idősebb - korábban combnyaktörés miatt operált - betegek ellenoldali csípőtáji törését követő halálozását és kockázati tényezőik kapcsolatát vizsgálta.

A nemzetközi irodalomban az ellenoldali csípőtáji törést követő halálozásról kevés és - különböző módszertana miatt - nehezen összehasonlítható adatok állnak rendelkezésre, kockázati tényezőikről még kevesebb információt találni.

Adataink szerint az egy hónapon belüli halálozás szempontjából legkritikusabb idószak az ellenoldali csípőtáji töréseknél az első két hónap (8,3\%/első hó, 9,0\%/ második hó), míg a primer töréseket [21] követően az első hónap (9,0\%/első hó, 6,5\%/második hó). A halálozási különbség okát fơként az ellenoldali csípőtáji törést szenvedett betegek magasabb átlagéletkorával és a kísérő betegségek nagyobb arányával (80,97 év, 96,8\%) magyarázzuk a primer törésekhez képest $(77,97$ év, 91,25\%) [21].

Jelen országos elemzésünkben az ellenoldali csípőtáji törést követő, 30 napon belüli halálozást 8,3\%-nak, a 365 napon belüli halálozást 38,4\%-nak, míg korábbi tanulmányunkban [21] a primer combnyaktörésekre vonatkozóan ugyanezen érékeket 8,9\%-nak és 30,7\%-nak találtuk. Park és mtsai [11] az 50 év feletti szekunder csípőtáji töröttek esetén az egy éven belüli halálozást 15,2\%-nak találták, amelyet hasonlónak ítélték meg Lee és mtsai [26] által a primer csípőtáji töröttek esetében talált 16,7\%-os egy éven belüli halálozással. Vizsgálatuk a dél-koreai lakosság 1,1\%-át érintette. Lee és mtsai [27] tajvani országos adatok alapján az 50 év feletti csípőtáji töröttek esetében a primer csípőtáji töréseket követően 14,1\%-os egy éven belüli halálozásról, míg a szekunder csípőtáji töréseket követően szignifikánsan magasabb, 18,8\%-os egy éven belüli halálozásról számoltak be, amit az előrehaladott életkorral és a kísérő betegségek nagyobb számával magyaráztak. Berry és mtsai [28] az első csípőtáji törésnél 15,9\%-os, a következő csípőtáji törésnél 24,1\%-os egy éven belüli halálozást igazoltak. Sawalha és Parker [29] a primer csípőtáji törés egy éven belüli halálozását 27,3\%nak, az ellenoldali szekunder csípőtáji törésekét szignifikánsan ( $\mathrm{p}=0,024)$ magasabbnak, 31,6\%-nak találták. Skála-Rosenbaum és mtsai [17] meglepő eredményre jutottak, miszerint az egy éven belüli halálozás a csak egyoldali csípőtáji törött betegeknél 27,9\%, míg az ellenoldali csípőtáji törést szenvedett betegeknél 22\% $(\mathrm{p}<0,001)$. Az ellentmondás hátterében jobb prognózist feltételeznek az ellenoldali csípótáji törött betegeknél, miután a primer csípőtáji törést követően a polimorbid betegek meghalnak. Holt és mtsai [24] a szekunder törések esetében 63\%-os, a primer töréseket követően 68\%-os egyéves túlélésról számoltak be $(\mathrm{p}=0,03)$. Sobolev és Parker [30] a havi átlagos mortalitási rátát primer törötteknél 16,2 (95\%-os CI: 16,0-16,4) /1000 beteg-hónapnak, szekunder törötteknél 21,1 (95\%-os CI: 20,2-22,1)/1000 beteg-hónapnak találták.

Az ellenoldali csípőtáji törést követő halálozás szignifikáns kockázati tényezőinek bizonyultak a 30 napon belüli halálozásnál a pertrochantaer töréstipus és a mütét hiánya, a 365 napon belüli halálozásnál az idósebb kor és az osteosynthesis mütéti típus. A férfi nemet és a kísérő betegségeket mindkét esetben halálozási kockázatot növelő prognosztikai faktorként értékeltük. A 30 napos túlélésanalízis alátámasztotta a töréstípusnál, a 365 napos túlélésvizsgálat a nem és a mútét típusánál tapasztalt különbségeket a mortalitásra vonatkozóan. 


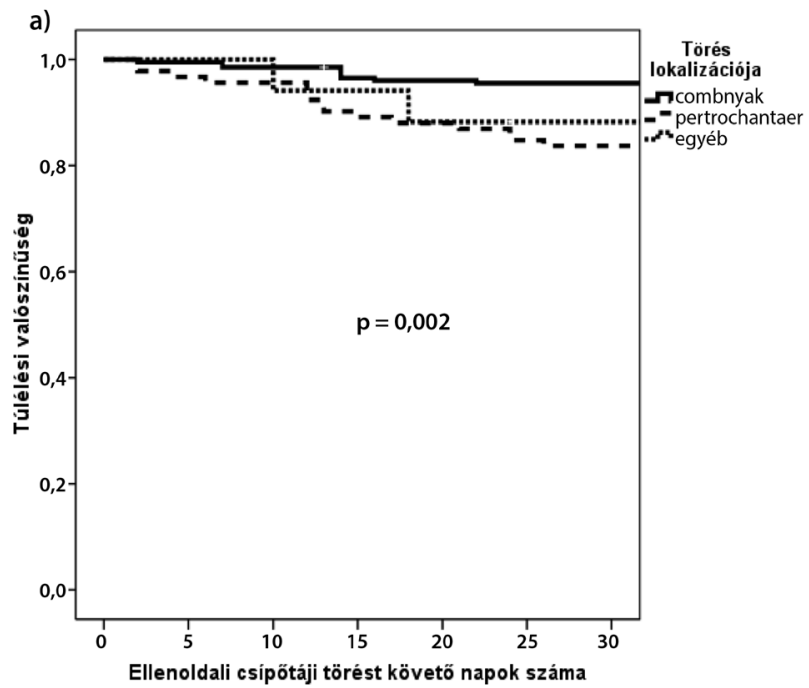

b)

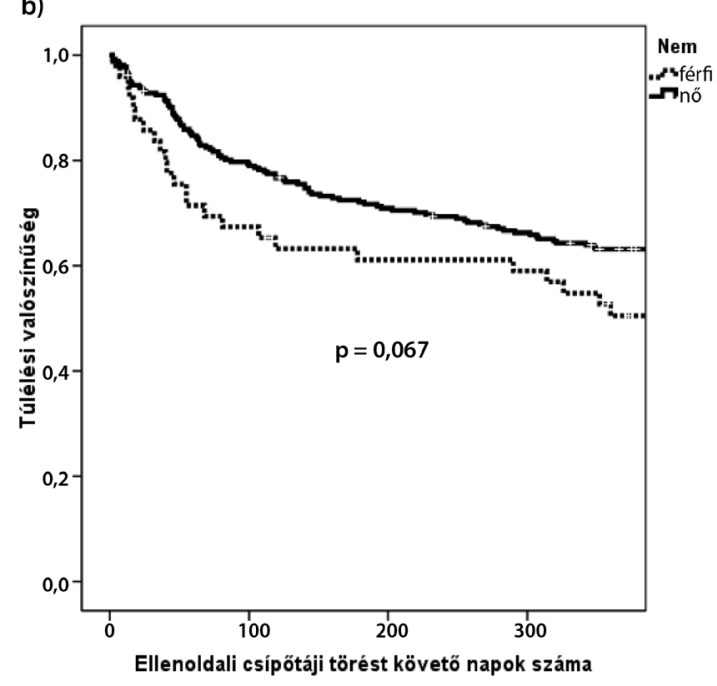

c)

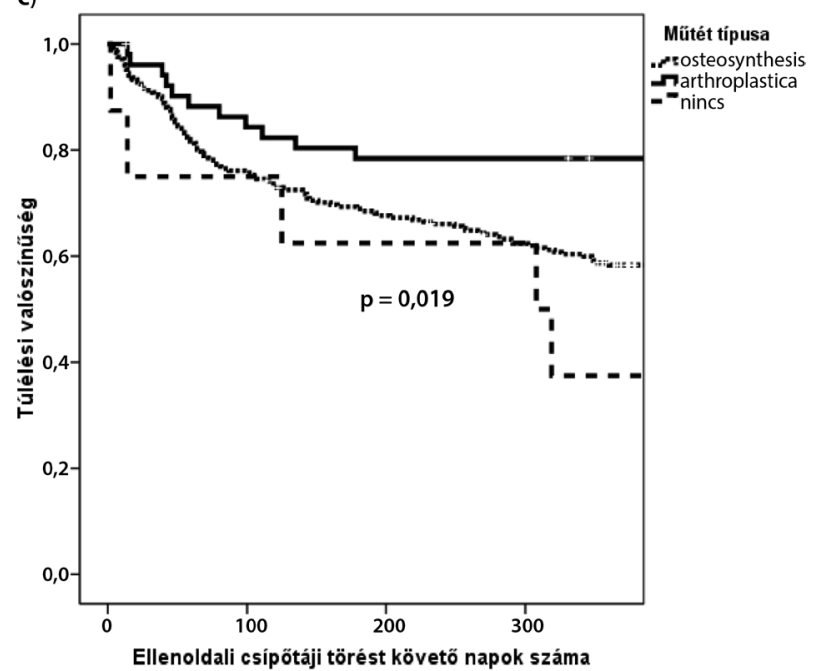

2. ábra

Kaplan-Meyer túlélési görbe az ellenoldali csípőtáji törést követő 30 nappal a) a törés lokalizációja, valamint 365 nappal b) a nem és c) a mútét típusa szerint
Az ellenoldali csípótáji töréseknél a mütét típusa szerint az egy éven belüli halálozási kockázat az arthroplasticai mütéteknél közel fele az osteosynthesis-mütétekhez képest, míg a mútét hiánya a 30 napon belüli halálozási kockázat hat-hétszeres emelkedését okozta. A mütéti típus - mint kockázati tényező - helyes értelmezéséhez hangsúlyozzuk, hogy nem a csontegyesítő (combfejmegtartó) osteosynthesis mütéti típus „eredményezi” a halálozási kockázat növekedését, hanem a beteg roszszabb általános állapota okozza. A csontegyesítő beavatkozások (például csavaros synthesisek) kis mútéti megterheléssel gyorsan kivitelezhetők, szemben az arthroplasticai (protézisimplantáció) mütétekkel. Így a rossz általános állapotú idősebb betegeknél csak az előbbi mútéti típus jelenti az egyetlen lehetséges operatív beavatkozást a mielőbbi mobilizáció érdekében, miközben a halálozási kockázat emelkedik. Legkritikusabb a helyzet a mútéti kontraindikációt eredményező nagyon rossz általános állapotú betegeknél, ahol az immobilizáció a 30 napon belüli halálozási kockázatot többszörösére emeli.

Eredményeink alapján a töréstipus szempontjából a pertrochantaer töréstípus több mint négyszeres kockázatot jelent a 30 napon belüli halálozásra a combnyaktörésekhez képest. A primer csípőtáji törések esetén a trochantertáji töréstípus halálozási kockázatot növelő hatásáról számoltak be Muraki és mtsai [31] az egyéves túlélésnél, Karagiannis és mtsai [32] az öt- és tíz éven belüli halálozásnál, míg Kesmezacar és mtsai [33] nem találtak szignifikáns különbséget a trochantertáji és combnyaktöréseket követő halálozás között. Haentjens és mtsai [34] a kórházi tartózkodás alatt $(\mathrm{p}=0,006)$ és az egy éven belüli halálozásnál $(\mathrm{p}=0,008)$ igazolták a trochantertáji törések halálozási kockázatnövelő hatását, amely szerintük nem magyarázható a kor és a kísérő betegségek különbségeivel, viszont felhívják a figyelmet a D-vitamin-státusz, a törékenység és az esési dinamika lehetőségeire. Véleményünk szerint a tomportáji töréseket követő magasabb halálozás hátterében a jobb vérellátás is szerepet játszhat, amelyet a jövőben tervezünk tovább vizsgálni.

Kor tekintetében szignifikánsan magasabb egy éven belüli mortalitást tapasztaltunk az idősebb, szekunder törést szenvedett betegek esetében, mint a fiatalabbaknál. Ryg és mtsai [15] is jelentősen magasabb mortalitást tapasztaltak a kor előrehaladtával az ellenoldali törést követően.

Adataink szerint a férfi nem közel kétszeres kockázatot jelent az ellenoldali csípótáji töréseket követő 30 napon és egy éven belüli halálozásra határérték-szignifikancia mentén. Lee és mtsai [27] szignifikánsan $(\mathrm{p}<0,01)$ magasabbnak találták az ellenoldali csípőtáji törés utáni egy éven belüli halálozást a férfiaknál $(17,4 \%)$, mint a nőknél (12,1\%), amely Ryg és mtsai [15] szerint is szignifikánsan $(\mathrm{p} \leq 0,05)$ magasabbnak igazolódott a férfiaknál $(27 \%)$ a nőkhöz (21\%) képest. 
A kisérő betegségek mortalitásra kifejtett hatása szempontjából kockázatnövelő tényezőnek tartjuk az ellenoldali csípótáji törötteknél, amely a korábbi tanulmányunk szerint [21] a combnyaktörést követő négy évben évenként bizonyult szignifikáns kockázati tényezőnek. Ryg és mtsai [15] nem találtak szignifikáns összefüggést a mortalitás és a kísérő betegségek között a Charlson-index vizsgálatával a szekunder csípőtáji töréseket követően. A jövőben a kísérő betegségek hatásának betegségcsoportonként történő vizsgálata differenciált információkkal bővítheti eddigi ismereteinket.

Tanulmányunk első limitációja, hogy a 2000-ben operált combnyaktörések esetében nem rendelkezünk információval a megelőző időszakban elszenvedett csípőtáji törések esetleges előfordulásáról, így az ellenoldali csípőtáji törésszámok alulbecsültek lehetnek.

Második limitáció, hogy tanulmányunk az ellenoldali csípőtáji törés idején fenálló kísérő betegséget vizsgálja a halálozás kockázati tényezőjeként, függetlenül a halálozás idejéig újonnan fellépő estleges további kísérő betegségektől.

Harmadik limitációként említjük, hogy a kísérő betegségek együttesen kerülnek értékelésre, differenciáltan történő vizsgálatuk, terjedelmük miatt, önálló tanulmány részét képezi a jövőben.

Tanulmányunk hiánypótló, mert a magyar populáció esetében ellenoldali csípőtáji törésekre vonatkozó halálozási adatok és kockázati tényezőik ez idáig nem kerültek közlésre.

\section{Következtetés}

Az ellenoldali csípőtáji törést követő halálozás az első két hónapban a legmagasabb, amely nemzetközi viszonylatban is magasnak számít. A halálozás szempontjából fokozott kockázatot jelent a tomportáji töréstípus, az idősebb kor, a férfi nem és a kísérő betegségek jelenléte. A mütét hiánya, illetve az osteosynthesis mútéti típus halálozásra kifejtett hatását a kísérő betegségek jelenlétére vezetjük vissza. A kockázati tényezők további vizsgálatának eredményei megalapozhatják az időskorban előforduló csípőtáji törésekkel összefüggő halálozást csökkentő hatékony preventív stratégia kialakítását.

A mortalitás csökkentése érdekében a csípőtáji törések menedzsmentjében a fokozott kockázatú betegeknél a halálozás szempontjából kritikus időszakban különösen fontosnak tartjuk az alapellátó és a szakellátó rendszer integrált interdiszciplináris együttmúködését.

Anyagi támogatás: A szerzők a közlemény megírásáért anyagi támogatásban nem részesültek.

Szerzői munkamegosztás: J. K., S. A.: Irodalomkutatás, információk szintetizálása, szövegezés. J. K., S. A., B. I.:
Adatelemzés. J. K., B. I., K. P., M. S., S. A.: Szakmai lektorálás, a kézirat szövegezésének véglegesítése. A cikk végleges változatát a szerzők elolvasták és jóváhagyták.

Érdekeltségek: A szerzőknek nincsenek érdekeltségeik.

\section{Irodalom}

[1] Sebestyén, A., Somogyi, P.: Epidemiology of osteoporosis. In: Lakatos, P., Takács, I. (eds.): Diseases of bone metabolism. [Az osteoporosis epidemiológiája. In: Lakatos, P., Takács, I. (szerk.): A csontanyagcsere betegségei.] Semmelweis Kiadó, Budapest, 2012, 174-180.

[2] Sebestyén, A., Péntek, M., Gulácsi, L., et al.: Modelling of burden of femoral neck fracture in 2007 from purchaser's point of view. [A combnyaktörések betegségteher-modellezése finanszírozói szemszögból.] Ca\&Csont, 2009, 12, 108-117. [Hungarian]

[3] Sebestyén, A., Boncz, I., Nyárády, J.: The analysis of health insurance costs of patients under 60 with medial femoral neck fracture treated primarily with screw fixation or hip replacement. [Az egészségbiztosítási költségek elemzése az elsődlegesen csavaros osteosynthesissel, illetve protézisbeültetéssel kezelt 60 évesnél fiatalabb medialis combnyaktörést szenvedett betegek eseteiben.] Orv. Hetil., 2006, 147, 1129-1135. [Hungarian]

[4] Sebestyén, A., Boncz, I., Dózsa, Cs., et al.: Cost analysis of pertrochanter fractrures according to the type of surgical treatment and the progressivity from the point of view of purchase. [Trochantertáji törések ellátásának költségvizsgálata a mútéti eljárások és a progresszív ellátási szintek szerint finanszírozói szemszögből.] Orv. Hetil., 2004, 145, 1115-1121. [Hungarian]

[5] Sambrook, P., Cooper, C.: Osteoporosis. Lancet, 2006, 367, 2010-2018.

[6] Péntek, M., Horváth, Cs., Boncz, I., et al.: Epidemiology of osteoporosis related fractures in Hungary by the nationwide health insurance database, 1999-2003. Osteoporos. Int., 2008, 19, 243-249

[7] Somogyi, P., Bossányi, A., Kricsfalusy, M., et al.: Assessment of the number of osteoporotic fractures in Hungary. [Az osteoporotikus eredetű csonttörések számának becslése Magyarországon.] Ca\&Csont, 2000, 3, 111-117. [Hungarian]

[8] Lakatos, P., Tóth, E., Szekeres, L., et al.: Efficiency of osteoporosis treatment in Hungary - an analysis of The Hungarian National Insurance company's data. [A csontritkulás kezelésének hatékonysága Magyarországon. Az Országos Egészségbiztosítási Pénztár adatainak elemzése.] LAM KID, 2012, 2, 5-12. [Hungarian]

[9] Dhanwal, D., Siwach, R., Dixit, V., et al.: Incidence of hip fracture in Rohtak, North India. Osteoporos. Int., 2011, 22, 629630.

[10] Emaus, N., Olsen, L. R., Abmed, L. A., et al.: Hip fractures in a city in Northern Norway over 15 years: time trends, seasonal variation and mortality: the Harstad Injury Prevention Study. Osteoporos. Int., 2011, 22, 2603-2610.

[11] Park, Y. G., Jang, S., Ha, Y. C.: Incidence, morbidity and mortality in patients older than 50 years with second hip fracture in a Jeju cohort study. Hip Pelvis, 2014, 26, 250-255.

[12] Burgers, P. T., Zielinski, S. M., Mailuhu, A. K., et al., Dutch femoral neck fracture investigator group: Cumulative incidence and treatment of non-simultaneous bilateral femoral neck fractures in a cohort of one thousand two hundred and fifty patients. Int. Orthop., 2014, 38, 2335-2342.

[13] Zhu, Y., Chen, W., Sun, T., et al.: Epidemiological characteristics and outcome in elderly patients sustaining non-simultaneous bilateral hip fracture: a systematic review and meta-analysis. Geriatr. Gerontol. Int., 2015, 15(1), 11-18. 
[14] Lawrence, T. M., Wenn, R., Boulton, C. T., et al.: Age-specific incidence of first and second fractures of the hip. J. Bone Joint Surg. Br., 2010, 92, 258-261.

[15] Ryg, J., Rejnmark, L., Overgaard, S., et al.: Hip fracture patients at risk of second hip fracture: a nationwide population-based cohort study of 169,145 cases during 1977-2001. J. Bone Miner. Res., 2009, 24, 1299-1307.

[16] Jubász, K., Boncz, I., Patczai, B., et al.: Risk factors for contralateral hip fractures following femoral neck fractures in elderly: analysis of the Hungarian nationwide health insurance database. Eklem Hastalik. Cerrahisi, 2016, 27, 146-152.

[17] Skála-Rosenbaum, J., Džupa, V., Bartoška, R., et al.: Subsequent contralateral hip fractures: can at-risk patients be identified? An observational study of 5,102 patients. Int. Orthop., 2015, 39, 755-760.

[18] Hu, F., Jiang, C., Shen, J., et al.: Preoperative predictors for mortality following hip fracture surgery: a systematic review and meta-analysis. Injury, 2012, 43, 676-685.

[19] Smith, T., Pelpola, K., Ball, M., et al.: Pre-operative indicators for mortality following hip fracture surgery: a systematic review and meta-analysis. Age Ageing, 2014, 43, 64-71.

[20] Simunovic, N., Devereaux, P. J., Sprague, S., et al.: Effect of early surgery after hip fracture on mortality and complications: systematic review and meta-analysis. CMAJ, 2010, 182, 16091616.

[21] Sebestyén, A., Boncz, I., Tóth, F., et al.: Evaluation of the correlation between risk factors and mortality in elderly patients with femoral neck fracture with 5-year follow-up. [Időskori combnyaktöréseket követő halálozás és kockázati tényezőik kapcsolatának értékelése 5 éves utánkövetéssel.] Orv. Hetil., 2008, 149, 493-503. [Hungarian]

[22] Zuckerman, J. D.: Hip fracture. N. Engl. Med., 1996, 334, $1519-1525$

[23] Dabl, E.: Mortality and life expectancy after hip fractures. Acta Orthop. Scand., 1980, 51, 163-167.

[24] Holt, G., Smith, R., Duncan, K., et al.: Outcome after sequential hip fracture in the elderly. J. Bone Joint Surg., 2012, 94, 18011808.

[25] Sobolev, B., Sheehan, K. J., Kuramoto, L., et al.: Excess mortality after second hip fracture. Osteoporos. Int., 2015, 26, 19031910.
[26] Lee, S. R., Ha, Y. C., Kang, H., et al.: Morbidity and mortality in Jeju residents over 50-years of age with hip fracture with mean 6-year follow-up: a prospective cohort study. J. Korean Med. Sci., 2013, 28, 1089-1094.

[27] Lee, S. H., Chen, I. J., Li, Y. H., et al.: Incidence of second hip fractures and associated mortality in Taiwan: A nationwide population-based study of 95,484 patients during 2006-2010. Acta Orthop. Traumatol. Turc., 2016, 50, 437-442.

[28] Berry, S. D., Samelson, E. J., Hannan, M. T., et al.: Second hip fracture in older men and women: the Framingham Study. Arch. Intern. Med., 2007, 167, 1971-1976.

[29] Sawalha, S., Parker, M. J.: Characteristics and outcome in patients sustaining a second contralateral fracture of the hip. J. Bone Joint Surg., 2012, 94, 102-106.

[30] Sobolev, B., Sheehan, K. J., Kuramoto, L., et al.: Excess mortality after second hip fracture. Osteoporos. Int., 2015, 26, 19031910.

[31] Muraki, S., Yamamoto, S., Ishibashi, H., et al.: Factors associated with mortality following hip fracture in Japan. J. Bone Miner. Metab., 2006, 24, 100-104.

[32] Karagiannis, A., Papakitsou, E., Dretakis, K., et al.: Mortality rates of patients with a hip fracture in a southwestern district of Greece: ten-year follow-up with reference to the type of fracture. Calcif. Tissue Int., 2006, 78, 72-77.

[33] Kesmezacar, H., Ayban, E., Unlu, M. C., et al.: Predictors of mortality in elderly patients with an intertrochanteric or a femoral neck fracture. J. Trauma, 2010, 68, 153-158.

[34] Haentjens, P., Autier, P., Barette, M., et al., Hip Fracture Study Group: Survival and functional outcome according to hip fracture type: a one-year prospective cohort study in elderly women with an intertrochanteric or femoral neck fracture. Bone, 2007, $41,958-964$.

(Juhász Krisztina dr., Pécs, Szabadság u. 7., 7623 e-mail: krisztina.juhasz01@gmail.com)

\section{A rendezvények és kongresszusok híranyagának leadása}

a lap megjelenése előtt legalább 40 nappal lehetséges, a 6 hetes nyomdai átfutás miatt. Kérjük megrendelőink szíves megértését.

A híranyagokat a következő címre kérjük: Orvosi Hetilap titkársága: edit.budai@akademiai.hu Akadémiai Kiadó Zrt. 